\title{
Effect of Different EGTA Concentrations on Dentin Microhardness
}

\author{
Antonio Miranda da CRUZ-FILHO ${ }^{1}$ \\ Eduardo Augusto de PAULA ${ }^{1}$ \\ Jesus Djalma PÉCORA² \\ Manoel Damião de SOUSA-NETO ${ }^{1}$ \\ ${ }^{1}$ Faculty of Dentistry, University of Ribeirão Preto, Ribeirão Preto, SP, Brazil \\ ${ }^{2}$ Department of Restorative Dentistry, Faculty of Dentistry of Ribeirão Preto, University of São Paulo, \\ Ribeirão Preto, SP, Brazil
}

\begin{abstract}
The effect of 1\%,3\% and 5\% EGTA (ethylene glycol-bis-( $\beta$-amino-ethyl ether) $\mathrm{N}, \mathrm{N}, \mathrm{N}^{\prime}, \mathrm{N}^{\prime}$-tetra-acetic acid) on the microhardness of root dentin of the cervical third of human teeth was studied. Five newly extracted maxillary incisors were sectioned transversely at the cementoenamel junction, and the crowns were discarded. The roots were embedded in blocks of high-speed polymerized acrylic resin and cut transversely into 1-mm sections. The second section of the cervical third of the root of each tooth was sectioned and divided into four parts. Each part was placed on an acrylic disc that was used as a base for microhardness measurement. Fifty microliters of $1 \%$ EGTA, 3\% EGTA, or 5\% EGTA were applied to the dentin surface. Deionized and distilled water was used as control. Dentin microhardness was then measured with a load of $50 \mathrm{~g}$ for $15 \mathrm{~s}$. Statistical analysis showed that the three concentrations of the chelating solution EGTA significantly reduced dentin microhardness when compared with water (ANOVA, $p<0.01$ ), and that there was a statistically significant difference among the three solutions (Tukey test, $\mathrm{p}<0.05$ ).
\end{abstract}

Key Words: dentin microhardness, chelating agents, EGTA.

\section{INTRODUCTION}

Endodontics is based on opening, cleaning, disinfecting, shaping and sealing the root canal system. Biomechanical preparation is essential for successful endodontic treatment and aims at cleaning and shaping root canals using irrigating solutions and suction. Instrumentation, one of the fundamental steps for the success of endodontic treatment, cannot be separated from the chemical procedure because, combined, these lead to successful endodontic therapy. There are many reasons for the use of chemical substances during biomechanical preparation such as variation of the root canal system internal anatomy where instrumentation is impaired due to difficulty of penetration of these instruments in all root walls (1).

Literature shows the importance of smear layer removal during or after the biomechanical preparation of the root canal with the association of chelating or chemical solutions and recently with the use of laser
(2). The chelating solution EDTA was proposed by Østby (3) to substitute the use of strong acids in atresic root canal decalcification, and more recently, EGTA was recommended $(4,5)$. EGTA has been used in medicine to obtain calcium-free environments (6-8). Specific calcium chelators such as EGTA have a more precise action on calcium ions leading to studies on the use of these as irrigating solutions during root canal biomechanical preparation.

Thus, the objective of this study was to evaluate in vitro the chelating effect of EGTA in different concentrations (1,3 and 5\%) on root dentin microhardness.

\section{MATERIAL AND METHODS}

Five recently extracted human maxillary incisors were sectioned transversely at the cementoenamel junction and the crowns were discarded. The roots were fixed in acrylic resin blocks and cut transversely in 1$\mathrm{mm}$ sections. Three sections of each third were ob- 
tained. After removing the acrylic resin, the second cervical section was divided into four parts. Each part was set in acrylic resin, with the cervical side facing up. The samples were then treated with $50 \mu \mathrm{l}$ of 1 of 4 solutions for 5 min using a micropipette: i) distilled and deionized water (control), ii) 1\% EGTA (Sigma Chemical Company, St. Louis, MO) (5), iii) 3\% EGTA (Sigma Chemical Company), and iv) 5\% EGTA (Sigma Chemical Company).

A Vicker's (Wolpert, Ludwigshafen, Germany) apparatus with a 50-g load applied for $15 \mathrm{~s}$ was used for dentin hardness measurement (9). A total of 12 microhardness measurements were made on each section, and the means were calculated.

Statistical analysis was conducted using parametric analysis of variance. When significance was detected, the Tukey test was used to determine statistical differences among the solutions.

\section{RESULTS}

The means obtained from the 12 measurements of each of the 5 samples representing dentin microhardness in different areas of the dentin ranged from 37.72 to 51.64 for water, 32.28 to 43.44 for $1 \%$ EGTA, 28.72 to 37.40 for $3 \%$ EGTA, and 26.16 to 31.58 for $5 \%$ EGTA.

Parametric analysis of variance showed a statistical significance $(p<0.01)$ for the softening effects of the solutions. The Tukey test showed statistically significant differences $(\mathrm{p}<0.05)$ among the solutions: deionized and distilled water $<1 \%$ EDTAC $<3 \%$ EGTA $<$ 5\% EGTA.

\section{DISCUSSION}

Since McComb and Smith (10) introduced the use of the scanning electron microscope in Endodontics, the influence of smear layer on the quality of endodontic sealing has been studied by many researchers. Smear layer is a negative factor when sealing the root canal because of its weak adherence to the root canal walls hindering sealer adhesion. Thus, the concern of removal before obturation to allow intimate contact of the sealer with the dentin surface (2).

After Østby's (3) proposal, the study of chelating solutions in dentistry has been exclusively related to EDTA and citric acid. In Medicine, chelating solutions are amply used and studied. The options are many and currently solutions specific to calcium such as EGTA are used (6-8).

The present study evaluated the effect of EGTA, which specifically chelates calcium, in different concentrations on root dentin microhardness, and evaluated its physical-chemical properties and its use as an irrigating solution in Dentistry. The different concentrations of EGTA were produced in neutral $\mathrm{pH}$, based on the Østby (3) study and distilled and deionized water was used as control because it does not interfere with dentin microhardness.

Cruz Filho et al. (5) reported that 15\% EDTAC and $1 \%$ EGTA similarly reduce root dentin microhardness. Thus, there is no difference in the indication of either for dentin tissue demineralization. Çalt and Serper (4) evaluated 17\% EGTA associated with $5 \%$ sodium hypochlorite and concluded that EGTA opens dentin canaliculi and removes smear plug. They also reported that EGTA is an alternative chelating agent for smear layer removal.

We believe that if low concentrations have the same effect as high concentrations, they should be preferred. Since EGTA has a satisfactory effect when compared to EDTA on dentin microhardness, it must be determined if a concentration less than $17 \%$ also removes smear layer.

Further studies should be carried out concerning EGTA before it can be used securely in clinical practice and its properties need to be better understood.

\section{RESUMO}

Cruz-Filho AM, de Paula EA, Pécora JD, Sousa-Neto MD. Efeito do EGTA em diferentes concentrações sobre a microdureza da dentina. Braz Dent J 2002;13(3):188-190.

Estudou-se o efeito da solução de EGTA (ácido bis(2-aminoetil) etilenoglicol-N,N,N',N'-tetraacético) a 1, 3 e 5\% sobre a microdureza da dentina radicular, no terço cervical de dentes humanos. Utilizaram-se 5 incisivos centrais superiores recémextraídos. Os dentes foram seccionados transversalmente na junção esmalte/cemento e as coroas foram desprezadas. As raízes foram incluídas em blocos de resina acrílica de rápida polimerização, colocadas em uma máquina de corte e seccionadas transversalmente de 1 em 1 milímetro. O segundo corte do terço cervical da raiz de cada dente foi selecionado para o experimento. Cada corte foi dividido em quatro partes sendo que cada parte foi colocada sobre um disco de acrílico, que servia de suporte para a medida de microdureza. Aplicou-se $50 \mu \mathrm{l}$ da solução teste durante cinco minutos sobre cada superfície de dentina. Água destilada e deionizada foi utilizada como controle. A microdureza 
da dentina foi medida em um aparelho de dureza Vickers com 50 gramas de carga e 15 segundos de aplicação. A análise estatística dos resultados mostrou que as 3 soluções quelantes reduziram significantemente a microdureza da dentina quando comparado com a água. As soluções de EGTA a 1, 3 e 5\% apresentaram-se estatisticamente diferentes entre si.

Unitermos: microdureza da dentina, soluções quelantes, EGTA.

\section{REFERENCES}

1. Barbizan JVB, Fariniuk LF, Marchesan MA, Pécora JD, Sousa Neto MD. Effectiveness of manual and rotary instrumentation techniques for cleaning flattened root canals. J Endodon 2002;28:365-367.

2. Sousa Neto MD, Marchesan MA, Pécora JD, Brugnera Junior A, Sousa YTCS, Saquy PC. Effect of Er:YAG laser on adhesion of root canal sealer. J Endodon 2002;28:185-187.

3. Østby NB. Chelation in root canal therapy. Ethylenediamine tetra-acetic acid for leasing and widening of root canals. Odont Tidskrift 1957;65:3-11
4. Çalt S, Serper A. Smear layer removal by EGTA. J Endodon 2000;26:459-461.

5. Cruz Filho AM, Sousa Neto MD, Saquy PC, Pécora, JD. Evaluation of the effect of EDTAC, CDTA and EGTA on radicular dentin microhardness. J Endodon 2001;27:183-184.

6. Carini R, De Cesaris MG, Bellomo G, Albano E. Role of Na+l $\mathrm{Ca} 2+$ exchanger in preventing $\mathrm{Na}+$ overload and hepatocyte injury: opposite effects of extracellular and intracellular $\mathrm{Ca} 2+$ chelation. Bioch Biophy Res Commun 1997;232:107-110.

7. Holroyd C, Kistner U, Annaert W, Jahn R. Fusion of endosomes involved in synaptic vesicle recycling. Mol Biol Cell 1999;10:3035-3044.

8. Lovik G, Larsen SK, Iversen JG, Rolstad B. C1qRp elicits a Ca++ response in rat NK cells but does not influence NK-mediated cytotoxicity. Scand J Immunol 2001;53:410-415.

9. Saquy PC, Maia Campos G, Sousa Neto MD, Guimarães LF, Pécora JD. Evaluation of chelating action of EDTA in association with Dakin's solution. Braz Dent J 1994;5:65-70.

10. McComb D, Smith DC. A preliminary scanning electron microscopic study of root canals after endodontic procedures. J Endodon 1975;7:238-242. 